pronounced over three-hour procedures, and appears proportional to the degree of manual activity within the team.

There is no doubt that palmar sweat contains a variety of substances capable of inactivating iodine. Unless the Disadine scrub is followed by a continuous release of available iodine throughout the operative procedure, failure to deal with recolonizing skin bacteria may be expected. This hypothesis is the subject of further studies.

The dominance of right and left hand contamination of surgeon and scrub-nurse respectively remains an unexplained observation. It was not due to a majority of left-handed nurses. In an earlier study in this unit Davidson (1969) showed glove puncture to occur most commonly on the left hand of the surgeon and the right hand of the scrub-nurse. This was thought to be due to the different way in which they handled suture needles. In the current trial the glove puncture rate remained constant throughout.

\section{Conclusion}

It is felt that the bacteriological result of this field trial adds significantly to the information required in an approach to an ideal surgical scrub technique. It is clear that on gloved hands Disadine failed to achieve the residual or cumulative antibacterial action shown by both Phisohex and Hibiscrub. Correlative interpretation of our own results with those of other workers suggest that of the small list of products available for the preparation of the hands of operating teams the new $4 \%$ chlorhexidine detergent performs as well if not better than
Phisohex during even the longest operative procedure. It has, moreover, a broader antibacterial spectrum, and produces a greater initial reduction of the bacterial contamination of the skin of the hands. It was found to be more acceptable in use and cheaper than either Disadine or Phisohex. These factors combined to convince the members of the trial team that Hibiscrub should now displace Phisohex in their surgical scrub regimen.

Gra:eful thanks are due to Dr. G. Hems for the statistical evaluat on, to Professor A. Macdonald for his helpful crit:cism of the parer, and to the theaire and medical staff for their co-operation.

\section{References}

Baber, K. G., et al. (1967). Fournal of Hygiene, 651, 381.

Curley, A., Hawk, R. E., Kimbrough, R. D., Nathenson, G., and Finberg, L. (1971). Lancet, 2, 296.

Davidson, A. I. G. (1969). Ph.D. Thesis, Aberdeen University.

Forfar, J. O., Gould, J. C., and MacCabe, A. F. (1968). Lancet, 2, 177.

Kimbrough, R. D. (1971). Archives of Environmental Health, 23, 119.

Lilly, H. A., and Lowbury, E. J. L. (1971). British Medical fournal, 3, 674.

Lowbury, E. J. L., and Lilly, H. A. (1960). British Medical fournal, 1, 1445.

Lowbury, E. J. L., Lilly, H. A., and Bull, J. P. (1960). British Medical fournal, 2,1039 .

Lowbury, E. J. L., Lilly, H. A., and Bull, J. P. (1963). British Medical Fournal, 1, 1251 .

Lowbury, E. J. L., and Lilly, H. A. (1973). British Medical fournal, 1, 510.

Michaud, R. N., McGrath, M. B., and Goss, W. A. (1972). Antimicrobial Agents and Chemotherapy, $2,8$.

Peterson, A. F. (1972). Development in Industrial Microbiology, vol. 14. In press.

Plueckhahn, V. D., and Banks, J. (1963). Lancet, 2, 519.

Price, P. B. (1938). Fournal of Infectious Diseases, 63, 301.

Selwyn, S., and Ellis, H. (1972). British Medical fournal, 1, 136.

Smylie, H. G., Webster, C. U., and Bruce, M. L. (1959). British Medical fournal 2, 606,

\title{
New Type of Allergic Asthma due to IgG "Reaginic" Antibody
}

\author{
D. H. BRYANT, M. W. BURNS, L. LAZARUS
}

\section{Introduction}

Though it is generally accepted that the antibodies responsible for immediate allergic reactions in man belong to one immunoglobulin class-IgE (Ishizaka and Ishizaka, 1967)-there is circumstantial evidence that other antibodies may be acting as reagins in some asthmatic patients.

It has been shown that circulating IgE levels may be normal in some allergic asthmatic subjects (Bennich and Johansson, 1971), and specific IgE antibodies have not been found in $25 \%$ of those who have a positive bronchial response to specific allergens (Aas and Johansson, 1971; Stenius et al., 1971). Furthermore, though disodium cromoglycate (DSCG) is an effective inhibitor of IgE-mediated allergic reactions (Cox, 1971), in several clinical trials it has been shown that it is effective in treating only $70 \%$ of patients with allergic asthma (Munro-Ford, 1971; Silverman et al., 1972). In addition disodium cromoglycate does not always suppress immediate allergic reactions elicited by bronchial provocation tests (Muittari, 1971).

Immediate allergic reactions in experimental animals are mediated by two types of antibody (Bloch and Ohman, 1971), one of these having the features of human $\operatorname{IgE}$, the other being an IgG antibody. There is one report of "short-term anaphylactic IgG antibodies" occurring in man, and that was in a group of patients with food allergy (Parish, 1970).

The present study was undertaken to determine whether a group of asthmatic patients with immediate allergic bronchial 
reactivity not due to IgE antibodies could be delineated. It was hoped that such patients might be further studied to show the nature of the antibody responsible for the immediate allergic reactions.

\section{Patients and Methods}

Bronchial provocation studies were carried out in 49 asthmatic patients (aged 14 to 63 years) to confirm the presence of immediate allergic reactivity of the bronchi. Each patient had multiple positive skin-prick reactions to common inhalant allergens, a positive result being defined as one with a weal greater than $3 \mathrm{~mm}$ in diameter, with a negative control test. This criterion was used because in a previous study (Bryant et al., 1973 a,b) skin reactions of this size were invariably accompanied by positive bronchial reactivity to the allergen in question. All subjects had a stable basal forced expiratory volume in one second $\left(\mathrm{FEV}_{1}\right)$ of greater than $2 \mathrm{l}$. which remained unchanged after inhaling Coca's solution for 15 minutes.

Extracts of the house-dust mite Dermatophagoides pteronyssinus (Commonwealth Serum Laboratories, Melbourne), plantain and rye-grass pollen, and the mould Aspergillus fumigatus (Bencard) were used for the provocation studies. A de Vilbiss 40 nebulizer (Drug Houses of Australia, Sydney) with an airflow of $8 \mathrm{l} . / \mathrm{min}$ was used to nebulize the extracts. Patients were tested with only one extract on any one day. They inhaled each extract until a positive bronchial reaction occurred or until the full skin testing strength solution had been inhaled for 20 minutes. A positive reaction was defined as a sustained fall in $\mathrm{FEV}_{1}$ of $20 \%$ or more of the basal reading, occurring within 15 minutes of inhalation. The tests were repeated two weeks later to determine the reproducibility of the results. The provocation studies were subsequently repeated 30 minutes after the patients had inhaled $20 \mathrm{mg}$ DSCG. The DSCG was said to have exerted a protective effect when double the dose of an allergen which had previously given a positive bronchial response could be administered before the $\mathrm{FEV}_{1}$ fell. Double-blind tests using DSCG and a placebo were carried out in 15 of the patients.

Serum IgE levels were measured by a radioimmunoassay technique (Bryant et al., 1973 b). in the 49 subjects and in 84 healthy controls with negative skin reactions. The results were expressed in units of the W.H.O. serum standard 68/341. The standard deviations of values obtained in this assay were $\pm 20 \mathrm{U} / \mathrm{ml}$ at a serum concentration of $500 \mathrm{U} / \mathrm{ml}$, and \pm 40 $\mathrm{U} / \mathrm{ml}$ at a serum concentration of $200 \mathrm{U} / \mathrm{ml}$.

The reaginic activity in the serum of 21 of the patients was examined by passive cutaneous anaphylaxis testing. This was carried out on adult monkeys (Macaca nemestrina) by standard techniques (Augustin, 1967). The $D$. pteronyssinus extract was used in all these tests because positive cutaneous and bronchial sensitivity to this allergen had been shown in all patients. Serial dilutions of serum from the 21 subjects were injected intradermally 24, 4, and 2 hours before the intravenous injection of Evans (azovan) blue and the allergen extract. Each serum sample was tested both unheated and after it had been heated for two hours at $56^{\circ} \mathrm{C}$. Each monkey received an intradermal injection of serum from a non-allergic asthmatic patient to exclude non-specific reactions.

The sera from these 21 patients were fractionated by the method outlined by Newcomb and Nelson (1973). Each serum sample was dialysed against $0.005 \mathrm{M}$ phosphate buffer $\mathrm{pH} 8 \cdot 0$ and then applied to a column of diethylaminoethyl-(DEAE)Sephadex A-50 (Pharmacia) which had been equilibrated in the same buffer. Adsorbed protein was fractionated by gradient elution with phosphate buffer $\mathrm{pH} 8.0$ of increasing molarity from 0.005 to 0.05 at a flow rate of $0.5 \mathrm{ml} / \mathrm{min}$. Protein peaks as determined by their optical density at $280 \mu \mathrm{m}$ were pooled and concentrated by ultrafiltration using a UM 10 Diaflo membrane. Residual IgE was removed from the IgG fraction by serial threefold gel filtration on a Sephadex G-150 column (Pharmacia). The IgG, IgA, and IgM content of the final concen- trates was measured by radial immunodiffusion (Behringwerke), and the IgE content by radioimmunoassay. The concentration of the immunoglobulin in these purified fractions was adjusted to correspond to that in the patients' whole sera, and the skin sensitizing activity of these fractions was then tested by passive cutaneous anaphylaxis in monkeys.

\section{Results}

All 49 subjects had a positive bronchial response to one or more allergens. The reproducibility of this response was confirmed by testing the patients on a second occasion. The mean variation in the dose of allergen needed to produce a comparable fall in $\mathrm{FEV}_{1}$ was $9 \%$.

DSCG exerted a protective effect in 37 subjects, no protection being conferred on the other 12 . On double-blind testing with DSCG and the placebo the placebo did not exert a protective effect in any of the subjects. It was not possible to predict on clinical grounds which patients would respond to DSCG. Statistical analysis of the two groups showed no significant difference in duration or severity of symptoms, age, number or size of positive skin reactions, or degree of blood eosinophilia. There was, however, a highly significant difference $(P<0.005)$ between the mean serum IgE levels in the two groups (see fig.). The mean IgE level in the patients responding to DSCG was $975 \pm 75 \mathrm{U} / \mathrm{ml}$ (S.E. of mean), and in the DSCG unresponsive group $250 \pm 53 \mathrm{U} / \mathrm{ml}$. Of the patients responding to DSCG the serum IgE level was greater than $400 \mathrm{U} / \mathrm{ml}$ in all but one (in whom the level was $380 \mathrm{U} / \mathrm{ml}$ ), and of the patients not responding to DSCG the IgE level was less than $400 \mathrm{U} / \mathrm{ml}$ in all. In addition there was a significant difference $(P<0.01)$ between the mean IgE value in the DSCG unresponsive group and that found in the 84 control subjects $(82 \pm 25 \mathrm{U} / \mathrm{ml})$.

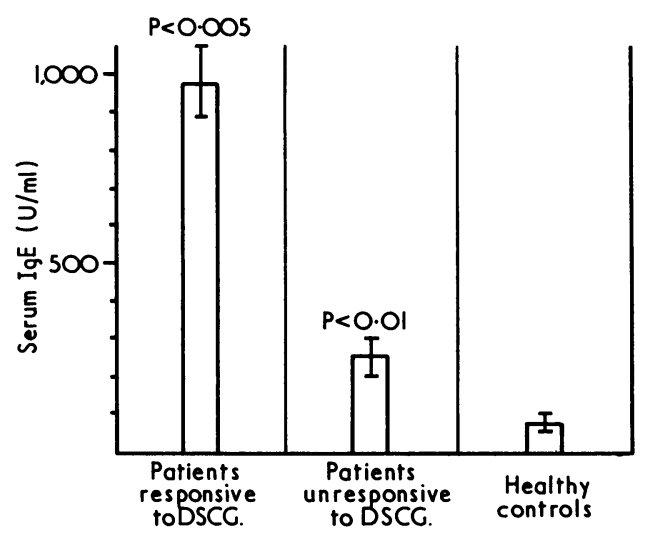

Mean serum IgE levels ( \pm S.E.) in asthmatic patients and controls.

Passive cutaneous anaphylaxis tests were carried out using the sera of 13 subjects who had serum IgE levels greater than $380 \mathrm{U} / \mathrm{ml}$ and in whom DSCG protection had been shown (group A). In each case heat-labile skin sensitizing antibody in high titre was detected which required a latent period of 24 hours to sensitize monkey skin (see table). Tests with sera from eight subjects who had serum IgE levels less than $400 \mathrm{U} / \mathrm{ml}$ and who were unresponsive to DSCG (group B) showed the presence of heat-stable, short-latency skin sensitizing antibodies. There was an obvious and highly significant difference $(P<0.005)$ between the results in these two groups. Two of the patients with high serum IgE levels (group A) had both types of skin sensitizing antibodies in their serum.

Analysis of the immunoglobulins isolated by column fractionation showed that the fractions eluted from the DEAE- 
Titre of Skin Sensitizing Antibody to D. pteronyssinus by Passive Cutaneous Anaphylaxis (P.C.A.) Testing in Monkeys

\begin{tabular}{|c|c|c|c|c|c|}
\hline \multirow{3}{*}{ Subject } & \multirow{3}{*}{$\begin{array}{c}\text { Serum } \\
\underset{(\mathrm{IgE} / \mathrm{ml})}{ }\end{array}$} & \multicolumn{3}{|c|}{ P.C.A. Titre } & \multirow{3}{*}{ Lability at $56^{\circ} \mathrm{C}$} \\
\hline & & \multicolumn{3}{|c|}{$\begin{array}{l}\text { Hours after } \\
\text { Sensitization: }\end{array}$} & \\
\hline & & 2 & & 24 & \\
\hline \multirow{2}{*}{\multicolumn{6}{|c|}{ Group A-Patients Responsive to DSCG }} \\
\hline 1 & & & & 64 & \multirow{11}{*}{ Labile } \\
\hline 2 & 380 & 0 & 0 & 128 & \\
\hline 3 & 605 & 0 & 0 & 128 & \\
\hline 4 & 780 & 0 & 0 & 128 & \\
\hline 5 & 1,125 & 0 & 0 & 128 & \\
\hline 6 & 850 & 0 & 0 & 256 & \\
\hline 7 & 920 & 0 & 0 & 256 & \\
\hline 8 & 925 & 0 & 0 & 256 & \\
\hline 9 & 1,420 & 0 & 0 & 256 & \\
\hline 10 & 1,150 & 0 & 0 & 512 & \\
\hline 11 & 1,250 & 0 & 0 & 512 & \\
\hline 12 & 1,025 & 8 & 8 & 256 & \multirow{2}{*}{$\begin{array}{l}\text { Antibody activity at } 2 \text { and } 4 \mathrm{hr} \\
\text { stable, at } 24 \mathrm{hr} \text { labile }\end{array}$} \\
\hline 13 & 1,300 & 16 & 32 & 512 & \\
\hline \multicolumn{6}{|c|}{ Group B-Patients Not Responsive to DSCG } \\
\hline & & & 8 & 0 & \multirow{7}{*}{ Stable } \\
\hline 15 & 85 & 8 & 8 & 0 & \\
\hline 16 & 145 & 16 & 16 & 0 & \\
\hline 17 & 380 & 16 & 16 & 0 & \\
\hline $\begin{array}{l}18 \\
19\end{array}$ & $\begin{array}{l}150 \\
260\end{array}$ & $\begin{array}{l}16 \\
16\end{array}$ & $\begin{array}{l}32 \\
32\end{array}$ & $\begin{array}{l}0 \\
0\end{array}$ & \\
\hline 20 & 345 & 32 & 32 & 0 & \\
\hline 21 & 255 & 32 & 64 & 0 & \\
\hline
\end{tabular}

Sephadex with $0.005 \mathrm{M}$ phosphate buffer contained IgG but less than $10 \mathrm{U}$ IgE per $\mathrm{ml}$ and less than $0.4 \mathrm{mg} \mathrm{IgM}$ and IgA per $\mathrm{ml}$. Those fractions eluted with $0.025 \mathrm{M}$ phosphate buffer contained $\mathrm{IgE}$ and a small amount of $\operatorname{IgA}$ and IgG. The IgG and IgA content was reduced to less than $0.3 \mathrm{mg} / \mathrm{ml}$ after serial gel filtration.

Repeating the passive cutaneous anaphylaxis studies with the immunoglobulin fractions confirmed that all the skin sensitizing activity was confined to the IgE fraction in the patients with heat-labile antibodies, while in the patients with short-latency, heat-stable antibodies the activity was confined to the IgG fraction. In the two patients with both heat-stable and heatlabile antibodies both the IgE and IgG fractions had skin sensitizing activity.

\section{Discussion}

These studies show for the first time that in the serum of asthmatic patients there are two different types of antibody which can mediate immediate allergic reactions. Most commonly these are IgE antibodies but may also be IgG antibodies. These two antibodies can be distinguished not only as they belong to different immunoglobulin classes but also as they give clearly different patterns of results on passive cutaneous anaphylaxis testing (Parish, 1970). A similar distinction has been described for antibodies responsible for immediate allergic reactions found in experimental animals (Levine, 1971). IgG antibodies which mediate this type of reaction have been named "short-term anaphylactic" antibodies (Parish, 1970). The results of these studies indicate that though DSCG inhibits reactions mediated by IgE antibodies it is not an effective inhibitor of IgGmediated immediate allergic reactions.

Apart from the response to a therapeutic trial of DSCG a distinction between allergic asthmatic patients with either $\operatorname{IgE}$ or IgG antibody could not be made on clinical grounds. Though the results reported here show that this can be achieved by means of passive cutaneous anaphylaxis testing these tests are not suitable for routine use. As all subjects in this study whose IgE level was greater than $400 \mathrm{U} / \mathrm{ml}$ had immediate bronchial reactions mediated by $\operatorname{IgE}$, and as all but one whose level was less than $400 \mathrm{U} / \mathrm{ml}$ had IgG-mediated reactions, these two groups of patients can be most conveniently distinguished by means of serum IgE estimations.

Until a larger number of patients have been studied it is difficult to estimate the proportion of allergic asthmatics in whom IgG-mediated reactions occur. Nevertheless, the results reported here together with the results of IgE surveys on allergic asthmatic patients (Bennich and Johansson, 1971; Stenius et al., 1971) and trials of DSCG in allergic asthmatics (Munro-Ford, 1971; Silverman et al., 1972) indicate that it may be as high as $20 \%$.

It is interesting to note that the mean IgE level in patients with IgG-mediated reactions was significantly higher than the mean IgE level in the non-allergic control subjects. Though no biological activity against common allergens could be found in the IgE fractions in these asthmatics this difference in $\operatorname{IgE}$ levels suggests that some asthmatics may have immediate allergic responses due to both IgE and IgG antibodies, as was, in fact, found in two other patients in this study.

It was not apparent from this investigation whether inherited or environmental factors played the major part leading to IgG rather than $\mathrm{IgE}$ antibody production. It is recognized that in both man and experimental animals the development of reaginic antibody is dependent on the allergic tendency of the individual, which is inherited as a polygenic characteristic, and on the degree of exposure of the individual to potential allergens (Pepys, 1969; Levine, 1971). There was no apparent difference in the exposure of the patients in this study to known allergens, and several patients had first-degree relatives with asthma whose response to DSCG suggested that the same antibody type is not always found in closely related subjects.

The ability to recognize these two different types of antibody which may mediate immediate allergic reactions in asthmatic patients has important clinical applications. As some patients benefit from its non-specific actions a trial of DSCG should not be withheld from a severely asthmatic patient (Altounyan, 1970). Nevertheless, a maximal response to this drug cannot be expected in all allergic asthmatic patients but only in those with IgE-mediated bronchial allergic reactions. The role of hyposensitization in the management of allergic asthmatic patients also needs to be reconsidered. Though there is disagreement over the place of this form of treatment, effective hyposensitization has been shown to decrease the allergic reactivity of the bronchi (McAllen, 1961; Assem and McAllen, 1973) and to be accompanied by an increase in serum total IgE and variable changes in serum titres of allergen-specific IgE (Connel' and Sherman, 1964; Assem and McAllen, 1973; D'Souza et al., 1973). The effect of hyposensitization on short-term anaphylactic IgG antibody is not known. As several patients in this series who had this type of antibody had noticed an exacerbation of their symptoms after hyposensitization had been attempted in the past it is possible that hyposensitization may have a harmful effect in these patients by stimulating this type of IgG antibody.

The recognition of these two different types of immediate allergic reactions in the bronchi of asthmatic patients is a notable advance in our understanding of the underlying immunological mechanisms in this disorder. It allows a more rational approach to treatment, explains the failure of existing forms of treatment in some patients, and will permit further investigation of these two different immunological reactions leading to more effective management of this common disease.

This work was supported by a grant from the Asthma Foundation of N.S.W. We should also like to thank Eli Lilley \& Co. for their support, and Fisons for supplying the DSCG placebo.

\section{References}

Aas, K., and Johansson, S. G. O. (1971). fournal of Allergy and Clinical Immunology, 48, 134.

Altounyan, R. E. C. (1970). Disodium Cromoglycate in Allergic Airways Diseas, , ed. J. Pepys and A. W. Frankland, p. 47. London, Butterworths. Assem, E. S. K., and McAllen, M. K. (1973). Clinical Allergy, 3, 161. Augustin, R. (1967). In Handbook in Experimental Immunology, ed. D. M. Weir, p. 1076. Oxford, Blackwell Scientific.

Bennich, H., and Johansson, S. G. O. (1971). Advances in Immunology, ed. F. J. Dixon and H. G. Kunkel, vol. 13, p. 1. New York, Academic Press. 
Bloch, K. J., and Ohman, J. L. (1971). Biochemistry of Acute Allergic Reactions, ed. K. F. Austin and E. L. Becker, p. 45. Oxford, Blackwell Scientific.

Bryant, D. H., Burns, M. W., and Lazarus, L. (1973 a). Australian and New Zealand fournal of Medicine, 3,104

Bryant, D. H., Burns, M. W., and Lazarus, L. (1973 b). Medical fournal of Australia, 2, 71 .

Connell, J. T., and Sherman, WX. B. (1964). Fournal of Allergy, 35, 169.

Cox, J. S. G. (1971). British fournal of Diseases of the Chest, 65, 189.

D'Souza, M. F., et al. (1973). Clinical Allergy, 3, 177.

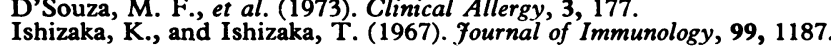

Ishizaka, K., and Ishizaka, T. (1967). fournal of Immunology, 99, 1187.
Levine, B. B. (1971). Biochemistry of Acute Allergic Reactions, ed. K. F.

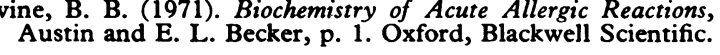

McAllen, M. K. (1961). Thorax, 16, 30.

Munro-Ford, R. (1971). Annals of Allergy, 29, 8

Muittari, A. (1971). Excerpta Medica International Congress Series, No. 232, p. 401 .

Newcomb, R. W., and Nelson, H. (1973). American fournal of Medicine, $54,174$.

Parish, W. E. (1970). Lancet, 2, 591.

Pepys, J. (1969). Hvpersensitivity Discases of the Lungs to Fungi and Organic Dusts, p. 1. Basle, Karger.

Silverman, M., Connelly, N. M., Balfour-Lynn, L., and Godfrey, S. (1972). British Medical fournal, 3, 378.

Stenius, B., Wide, L., Seymour, W. M., Holford-Strevens, V., and Pepys, J. (1971). Clinical Allergy, 1, 37.

\section{MEDICAL MEMORANDA Fat Embolism after Pertrochanteric Venography}

\author{
A. E. YOUNG, I. LYNN EVANS, D. IRVING \\ C. D. HANNING
}

British Medical fournal, 1973, 4, 592

Pertrochanteric venography is a useful and usually safe procedure which has gained widespread application in the investigation of the pelvic and iliac veins when pedal or perfemoral techniques are inappropriate. A case is here reported where pertrochanteric venography was complicated by a classical fat embolism syndrome.

\section{Case Report}

A man ased 54 was admitted to hospital complaining of a swelling of the right leg present for six weeks. Thirteen years previously he had suffered a venous thrombosis in the same leg complicated by pulmonary embolism. There was no history of cerebrovascular or cardiac disease and he was normotensive. $\mathrm{He}$ was thought clinically to be suffering from a right iliofemoral thrombosis. In the course of the investigation of this, right pertrochanteric venography was performed. Two separate injections of $30 \mathrm{ml}$ of angiografin (diatrizoic ac:d) were given plus test injections of $5 \mathrm{ml}$ before each series of films. The injections were made through a Lea Thomas needle using hand pressure only (Lea Thomas 1969). The procedure was carried out under general anaesthesia and was uneventful. Eight hours later he became transiently hypotensive $(80 / 60 \mathrm{~mm}$ $\mathrm{Hg}$ ) but was otherwise well. After 18 hours he became sleepy, dysarthric, and confused and was pyrexic $\left(38^{\circ} \mathrm{C}\right)$ and incontinent of urine.

When examined he was found to be sweating profusely; there was a tachycardia of $100 / \mathrm{min}$ and a tachypnoea of $36 / \mathrm{min}$ but no cyanosis. His chest was clear on auscultation but on examination of the nervous system the pupils were noted to be constricted and there was symmetrical hyperreflexia with sustained clonus of the ankles. Both plantar reflexes were extensor. Four hours later a fine petechial rash appeared on the face, trunk, arms, conjunctivae, and oral mucous membranes. Many fat globules were seen in the urine on microscopy. Blood gas estimation showed Po. $65 \mathrm{~mm} \mathrm{Hg}$ and PCO., $30 \mathrm{~mm} \mathrm{Hg}$. chest radiography and E.C.G. showed nothing abnormal. The haemoglobin was $12.6 \mathrm{~g} / 100 \mathrm{ml}$ and there was no growth on blood cultures. The patient was thought to have suffered a fat embolism and was therefore treated with continuous oxygen, low molecular weight dextran (500 ml six-hourly), with hydro-

Lewisham Hospital, London SE13 6LH

A. E. YOUNG, F.R.C.S., Surgical Registrar (Present address: Department of Surgery, St. Thomas's Hospital, London SE1 7EH)

I. LYNN EVANS, F.R.C.s., Consultant Surgeon

D. IRVING, M.B., D.M.R.D., Consultant Radiologist

C. D. HANNING, M.B., B.s., House Surgeon cor isone ( $200 \mathrm{mg}$ intramuscularly six-hourly), and ampicillin (500 mg six-hourly).

The confusion cleared within two days and the blood gases r'turned to normal in four. The patient was eventually discharged well 17 days after the initial incident, the only residual sign being slight hypertonicity in the legs.

The patient was not heparinized after the initial episode, as this may be harmful in the presence of fat embolism (British Medical fournal, 1970). He was, however, given anticoagulant treatment by mouth after seven days without ill effect.

\section{Comment}

The symptoms in this case were clearly diagnostic of a systemic fat embolism, fitting exactly the diagnostic profile described by Thomas and Ayyar (1972). Many would accept the findings of lipuria as confirmatory; furthermore, the time of development of the symptoms tie its origin to the performance of venography.

Of the two theories about the mechanism of fat embolism we believe the theory of Gauss (1924), in which the embolism is considered to be of marrow fat forced into the circulation through ruptured venules, to be the primary explanation in this instance rather than Lehman and Moore's (1927) theory of changed intravascular emulsion stability. Whitenack and Hausberger (1971) found that ${ }^{131} \mathrm{I}$-labelled triolein and olive oil injected into the tibial marrow cavity of rabbits passes rapidly to the lung when the marrow cavity pressure exceeds $50 \mathrm{~mm} \mathrm{Hg}$, and this effect is more readily obtained in unfractured bone than fractured bone. (Hausberger and Whitenack, 1972). It is hardly surprising that during pertrochanteric venography some fat as well as contrast medium may be passed into the circulation, and a study is in progress to determine whether subclinical fat embolism is regularly produced during this procedure. The present report, however, appears to be the first on the development of a full fat embolism syndrome after pertrochanteric venography. We were not able to identify any abnormal feature in the technique of venography that might have precipitated embolism on this occasion.

We believe that an awareness of the possibility that fat embolism syndromes may result from pertrochanteric venography is important, for some of these syndromes may mimic pulmonary embolism in patients in whom pulmonary embolism, while not necessarily expected, is being watched for. Pertrochanteric venography should nevertheless continue to be regarded as a safe and indispensible technique for the investigation of pelvic venous disease.

\section{References}

British Medical fournal, 1970, 3, 476.

Gauss, H. (1924). Archives of Surgery, 9, 593

Hausberger, F., and Whitenack, S. H. (1972). Surgery, Gynecology and Obstetrics, 134, 931

Lea Thomas, M. (1969). British fournal of Radiology, 42, 352.

Lehman, E. P., and Moore, R. M. (1927). Archives of Surgery, 14, 621.

Thomas, E. J., and Ayyar, D. R. (1972). Archives of Neurology, 26, 517

Whitenack, S. H., and Hausberger, F. (1971). American fournal of Pathology 65,357 . 